\title{
Analyzing Professional English Learning Needs and Situations of Science and Language Majors in a Chinese University
}

\author{
Qing Xie ${ }^{1}$ \\ ${ }^{1}$ School of Foreign Studies, Jiangnan University, Wuxi, People's Republic of China \\ Correspondence: Qing Xie, 1800 Lihu Avenue, Wuxi 214122, Jiangsu, People's Republic of China. Tel: \\ 0086-138-1252-9087. E-mail: princessjane2000@ hotmail.com
}

$\begin{array}{lc}\text { Received: April 3, } 2019 & \text { Accepted: April 18, } 2019 \quad \text { Online Published: May 2, } 2019 \\ \text { doi:10.5539/hes.v9n2p141 } & \text { URL: https://doi.org/10.5539/hes.v9n2p141 }\end{array}$

\begin{abstract}
This article reports an investigative study of professional language learning needs of science and language majors in the Chinese university context. Surveys with both rating and open-ended questions and participant observation were conducted with 158 participants from science and language programs who enrolled in business English courses in the Chinese university in February 2017. The results show that science and language majors had different purposes for learning professional English as they had discipline specific learning needs. Language majors had more communication with English users than science majors. However both science and language majors reported limited English language use and learning out of class. There were difficulties in English learning due to lack of motivation and interest. Based on the results, suggestions are offered for teaching improvement. This study has positive implications for college English teaching reform in both China and worldwide context.
\end{abstract}

Keywords: professional English learning needs, situations, science major, language major, Chinese university

\section{Introduction}

As early as in the year 2004, the Ministry of Education, China has issued the report of education reform and development. The report indicates a strengthened effort to improve teaching quality and implement teaching reform in higher education institutions. There will be further endeavor to enhance talent quality and the development of universities of international standards with major disciplines.

Under this background of transformation in the Chinese higher education context, the college English teaching reform has also been carried out for 30 years. During this period, the college English teaching has been evolving from the mode of delivering to guiding and autonomy of the learning process. One of the key issues is to understand the perceptions of teachers and students, as the effectiveness of teaching practice is related to students' own international perspective and lifelong learning competence (Mao, 2015). It is recognized that needs analysis is an essential step in college English teaching and learning in China (Zheng, 2010).

In light of the trend, this study aims to investigate the English language learning needs and situations under the disciplinary background. The study compares and contrasts the professional English language learning needs and situations of language and science majors. The disciplinary influences on the English language learning needs and situations are particularly explored. This study offers unique empirical insights into the English language learning context in the Chinese university, which may inform college English teaching and curriculum reform for various situations. Based on the investigations, suggestions are offered for college English teaching and learning in China. Thereby, this study mainly addresses the following two research questions:

(1) What are the professional English learning needs and situations of science and language majors in China?

(2) What are the similarities and differences in the professional English learning needs and situations of science and language majors in China?

\section{Literature Review}

\subsection{The Theories and Process of Needs Analysis Research}

The theories of needs analysis research is initially rooted in the literature of English for specific purposes (ESP). According to Dudley-Evans and St John (1998), needs analysis is the basis for course development. Needs 
analysis consists of the steps of "target situation analysis, learning situation analysis and present situation analysis" (p.123). Typical information gathered in the needs analysis stage includes "learner's personal information, learners' lacks, curriculum needs, language learning needs, learner's professional information and target language information" (p.125). For learners in ESP, Strevens (1988) categorizes them as English learners for academic studies and English learners for occupation. The learners may be learning ESP in parallel with their academic study or occupational tasks. Teachers need to be able to "recognize learner's progress and diagnose the problems" (p.39) in addition to the knowledge about the materials and methodology. As basic concerns for ESP courses, Cheng (2011) indicates the necessity for gathering information such as the learner group profile, learning objectives and learner performance as a part of the course design process.

According to Robinson (1991), needs analysis practice uses the instruments of "questionnaires, interviews, observation, case studies, tests and authentic sample collection" (p.12). Long (2012) more recently indicates that the sources of needs information include "literature, learners, teachers, domain experts and triangulated sources" (p.25). Long (2012) also includes in the needs analysis methodologies such instruments as "ethnographic methods, diaries and content analysis etc." (p.31). In the later study such as by Serafini, Lake and Long (2015), triangulation of information from multiple sources and combination of various data collection instruments are recommended.

\subsection{Analyzing Professional English Learning Needs in the Academic Context}

Analyzing professional English learning needs in the academic context tend to involve stakeholders, such as faculties, students, alumni and employers. For example, Lebanon, Bacha and Bahous (2008) investigate the needs of business students in English language proficiency and writing and the views of faculties in the university. According to the research, the students were not up to the standards required for writing in different genres and it is suggested that business and language faculties should cooperate to address the inadequacy. In Thailand, Kaewpet (2009) identifies the communication needs of civil engineering students by interviewing stakeholders including employers, teachers and ex-students. The related reading, writing and speaking tasks are recommended to be parts of the course content. More professional English courses related to civil engineering are suggested.

Other studies focus on discipline specific learning needs. For example, in Spain, Peters and Fernández (2013) explore the lexical needs of postgraduate students in architecture. There is less concern with architecture terminologies than common ones shared with science disciplines. They rely on both bilingual and monolingual dictionaries to decode the terminologies, which is considered essential skills for the future workplace. In Austria, Trinder (2013, p.1) investigates business students' beliefs of language learning using questionnaires with rating and open-ended questions and qualitative interviews. It is found that business students share certain conceptions and traits. Successful learners demonstrate higher-level of autonomy and "beneficial beliefs of language learning".

\subsection{Previous Needs Analysis Research in the Chinese Context}

In the Chinese university context, needs analysis research focuses on both English major and non-English major undergraduates. Target situation analysis is also sometimes conducted with key industrial practitioners. Zheng (2015) conducts needs analyses with English major students and graduates on the target language needs and learners' learning needs. The results show that the business English courses under study have focus on reading, rather than practical communicative competence development. More communicative language teaching methods such as role play and simulation should be developed for the business English courses. In another Chinese university context, Bao (2016) conducts needs analysis surveys with English major undergraduates from year one to year three about language information, learning difficulties and educational environment under the background of educational reform. The majority of the participants consider speaking as the most important skill, followed by listening and translation.

Other studies in the Chinese university context have focused on language learning needs and situations in different disciplines. For example, Li and Zhang (2010) conduct needs analysis research with 107 undergraduates from nursing program using questionnaires. According to the study, students hope to engage more with the teaching process. They hope to have tailored learning program combining classroom teaching with multimedia technology. Chen, Zhou, Jiang and Wang (2012) conduct target situation analysis with logistic industry practitioners and present situation analysis with logistics major students from three universities in one coastal city of China. The study recommends improving the quality of input and students' interest. The study also calls for the improvement in language output and the communicative competence development in the real world situations. In Macau, China, in order to improve the students' tourism English communicative competence, 
needs analyses with students, teachers and tourism industry practitioners are conducted in order to find existing problems in teaching. Suggestions are given for improving the teaching practices (Leong \& $\mathrm{Li}, 2012$ ).

\section{Methodology}

Based on the literature review, it is shown that most needs analysis research focuses on one academic discipline. There are few empirical studies which compare and explore the influences of disciplinary differences on English learning needs and situations. Under the background of English teaching reform in China, this study aims to investigate the professional English learning needs and situations of science and language majors.

The nature of needs analysis research requires both numerical and descriptive information (Brown, 2014). This study adopts the survey-based method of both quantitative and qualitative nature, as the survey instrument includes both rating and open-ended question. Moreover, in order to better supplement the results from the surveys, the study also adopts participant observation as one of the usual needs analysis approaches, to complement the information from the survey. The details of data collection, participants and data analysis are provided in the following sections.

\subsection{Data Collection}

Paper-based survey questionnaires (see Appendix) with one rating and fourteen open-ended questions were administered to 158 participants who enrolled in business English courses in the period of February to May 2017 in a public university in the east of China. The business English courses are managed by college English department of the university. The questions were adapted from the needs analysis framework by Basturkmen (2010, p.21) and Dudley-Evans and St John (1998, p.140), which ensured the validity and reliability of the survey instrument. The survey questionnaires explore participants' perceptions of the usual types of methodologies in the academic study, the importance and roles of professional English in academic study, English use situations and contexts, English learning situations and roles of business English for their career development. The questionnaire in English was translated into Chinese. The translated version of the survey was edited by another senior Chinese researcher who had knowledge of both Chinese and English research. The verified translated version of the survey was then administered to participants. All of the participants answered the questions in Chinese to ensure the information provided is thorough. The response rate is $100 \%$.

In addition, researcher also delivered the business English courses from February to May 2017. This enables researcher's participant observation and reflection so that insider views can be obtained, to help interpret the data gathered from paper-based survey questionnaires.

\subsection{Participants}

The participant profiles are summarized in Table 1. Among the participants, 31\% are male and $69 \%$ are female. Their average age is 20.2 years old. Their age range is $18-22$ years old. Around $75 \%$ are in their second year while $25 \%$ are in the third year of study in this public university in the east of China. Around $68 \%$ of the participants have passed College English Band-4 (CET-4) while 11\% of them have passed College English Band-6 (CET-6). One participant also recorded an International English Language Test System (IELTS) score of 5.5.

Table 1. Participant Profiles

\begin{tabular}{ll}
\hline Variables & Number (Percentage) \\
\hline No. of participants & 158 \\
Male & $49(31 \%)$ \\
Female & $109(69 \%)$ \\
Average age & 20.2 years old \\
Age range & $18-22$ years old \\
Pass CET-4 & $108(68 \%)$ \\
Pass CET-6 & $17(11 \%)$ \\
Second year of study & $118(75 \%)$ \\
Third year of study & $40(25 \%)$ \\
\hline
\end{tabular}

Details of the academic programs participants enroll are provided in Figure 1. About 21\% of the participants enroll in bioscience programs, including brewing. About $23 \%$ enroll in food science and engineering programs, including food quality. They are grouped as participants from science program in the study. About $56 \%$ of the participants are in the Japanese program, offered by the School of Foreign Studies. They are grouped as 
participants from language program in the study.

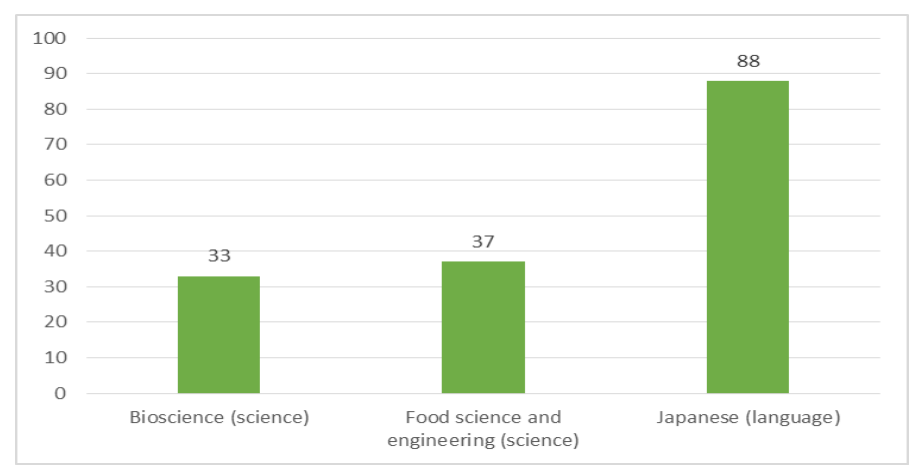

Figure 1. Academic Programs Participants Enroll

Participants' self-assessment of business English level is described in Figure 2. It can be seen that $37 \%$ of the participants are at the beginner level. Over $20 \%$ of the participants described themselves at low intermediate and intermediate respectively. $14 \%$ of the participants described themselves as high beginner. Only $2 \%$ of the participants were considering themselves at high intermediate level. There are no self-assessment at advanced or native levels.

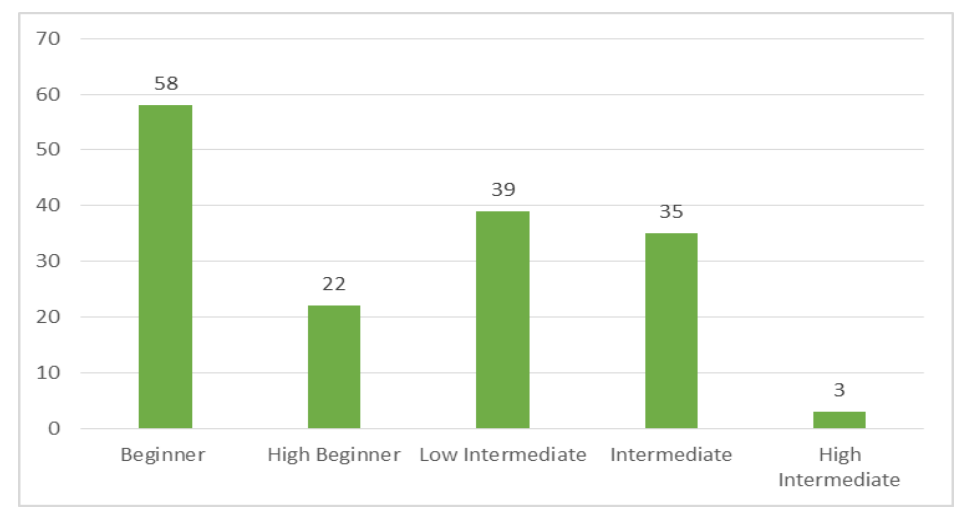

Figure 2. Business English Level Self-assessment

Participants' motivation to study English is described in Figure 3. About $66 \%$ of the participants had medium motivation to study English. About $18 \%$ had low motivation while $16 \%$ had high motivation.

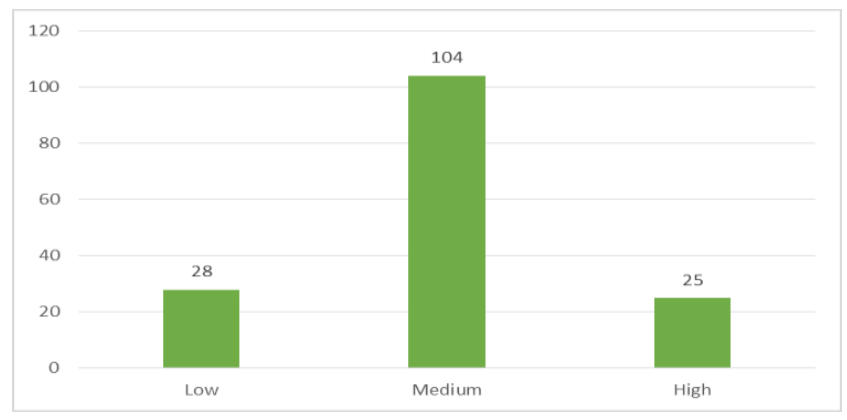

Figure 3. Motivation to Study English

The reasons for participants to study business English are provided in Figure 4. Over one third of the participants hoped to improve their English communication skills so that they can better prepare for prospective overseas or graduate study. About $20 \%$ of the participants were more motivated by career development. They mentioned the business English skills would be useful in the future workplaces. About $7 \%$ of the participants considered 
business English as useful, practical and interesting. Another 7\% hoped to learn more business or economics knowledge and to expand their horizon. About 5\% of the participants hoped business English learning could help them to pass Business English Certificate (BEC) test or CET-4 and CET-6. Only 4\% of the participants were driven by personal interest in the subject.

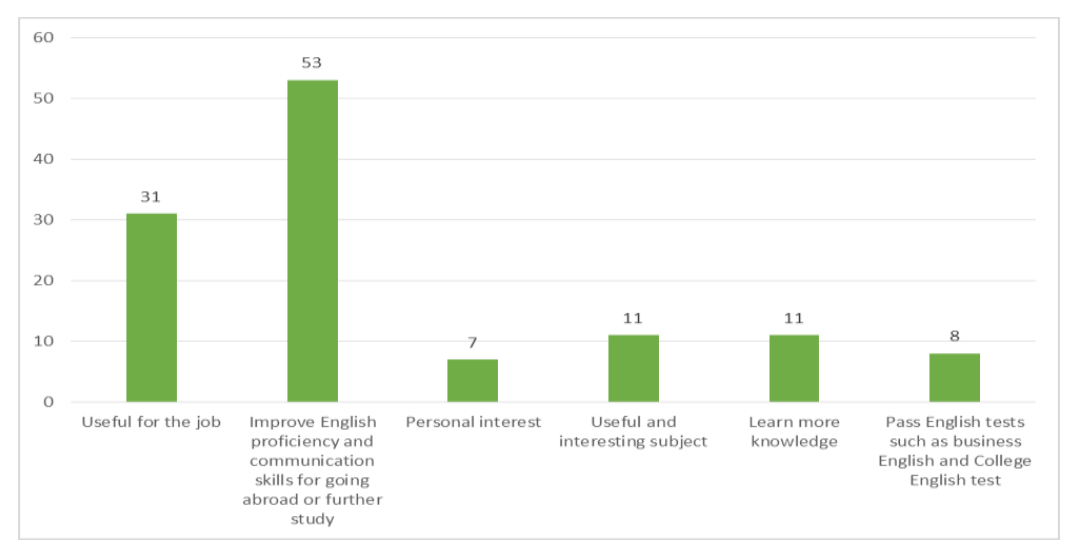

Figure 4. Reasons to Study Business English

\subsection{Data Analysis}

The information gathered from survey questionnaires were categorized by themes, to address different aspects of professional English learning needs and situations of science and language majors. A content analysis was conducted for the survey responses (Dörnyei \& Taguchi, 2011, p.99). For rating questions, the frequency and mean were calculated. For open-ended questions, the frequency of the themes in the responses and the percentage of participants were calculated, which are then presented in Figure 5 11. Best quotes (Guest, MacQueen \& Namey, 2012) were drawn from the responses and translated into English by researcher to demonstrate the unique English learning needs and situations. Moreover, researcher's participation observation and reflection is documented for better understanding of the insight gained from questionnaires.

\section{Results}

\subsection{Professional English Learning Needs and Situations of Science and Language Majors in China}

\subsubsection{The Usual Types of Class Activities}

The participation in class discussion in the academic study is described in Figure 5. Around 87\% of the science major participants had to take part in class discussion. Around $23 \%$ of them had class discussion once a week. About $9 \%$ of the participants had class discussion every class. 20\% of them occasionally had class discussion.

In comparison, $90 \%$ of language major had to join in class discussion. Around $16 \%$ language major participants had discussion every class. About $15 \%$ of them had class discussion once a week. About $6 \%$ of them had discussion even 2-4 times a week.

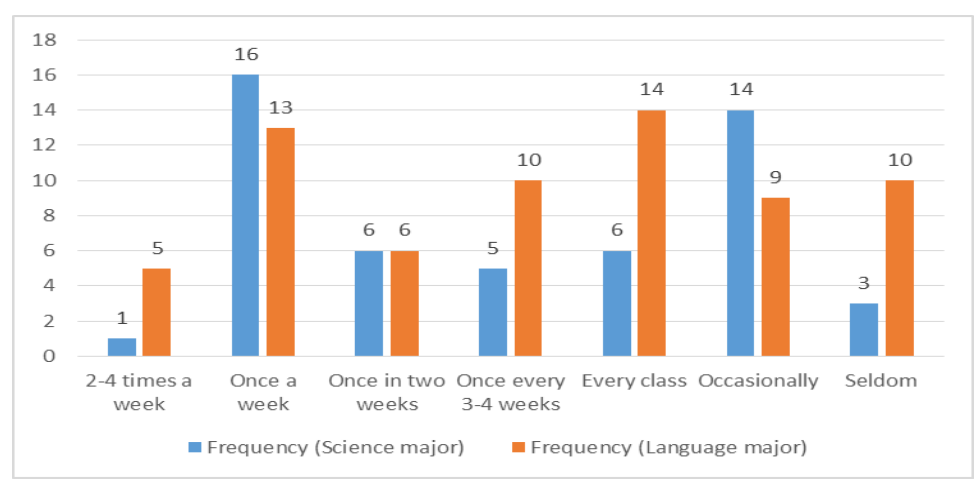

Figure 5. Participation in Class Discussion in the Academic Study

The participation in presentation in class is described in Figure 6. About $41 \%$ of science major participants had to give presentations in their program study. Around $16 \%$ of them gave twice or three times presentations per 
semester. About $10 \%$ of the participants gave presentations once or twice a month. About $6 \%$ of the participants gave presentations once a semester while $4 \%$ gave presentations once a week. One participant who did not give presentation in class indicated the unwillingness to do the task.

Comparatively speaking, $56 \%$ of language majors gave presentations in their academic study. About $18 \%$ of language majors gave presentations once a semester. About $8 \%$ of them gave presentations once a week. About $7 \%$ of them gave presentations twice or three times a semester. Around $6 \%$ of them gave presentations once or twice a month. However, $8 \%$ of them seldom had presentations in class.

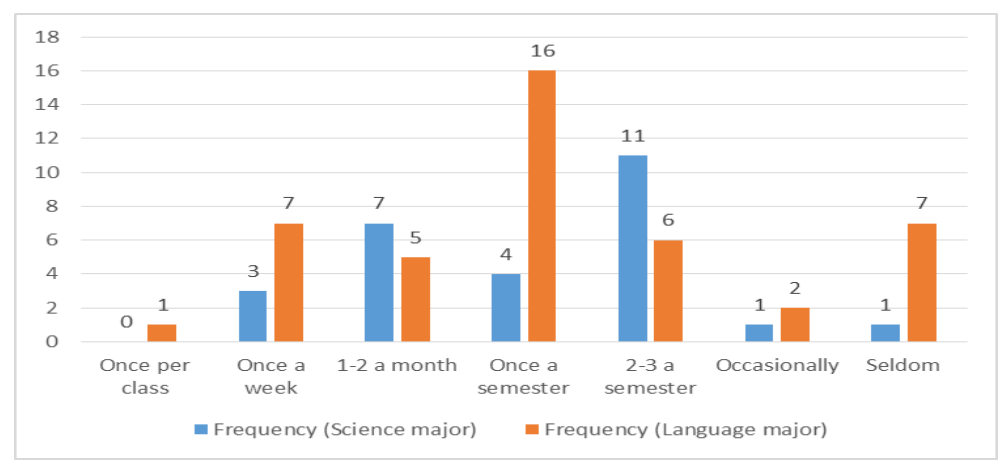

Figure 6. Participation in Presentation in the Academic Study

\subsubsection{The Importance and Roles of Professional English in Academic Study}

For science and language major participants, their rating for the importance of professional English skills to academic study is described in Figure 7. For science majors, professional English reading had the highest mean of 4.2 followed by professional English listening and professional English speaking. Professional English writing had the lowest mean of 3.6. For language major participants, professional English speaking, listening and reading had the equal mean of 4 while professional English writing was lower at 3.1.

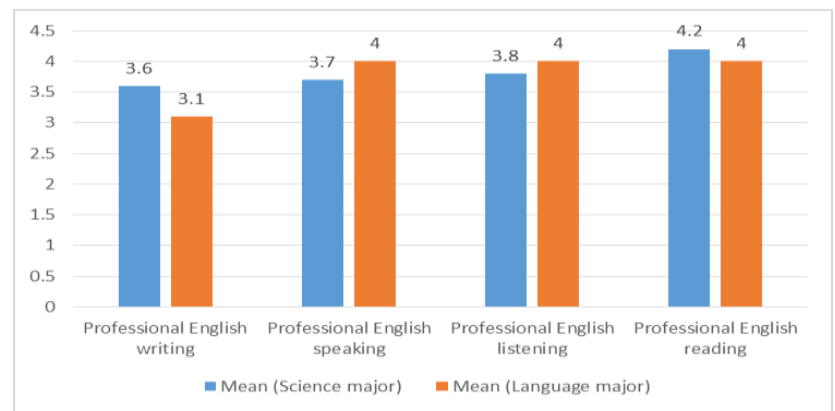

Figure 7. The Importance of Professional English Skills to Academic Study by Mean of the Rating of 0 5 with 0 Meaning not Important at All while 5 Meaning very Important

For science majors, the roles of English in the academic study is described in Figure 8. About 59\% of the science major participants mentioned reading English literature as the most important use of the language. Participant M had the following observation:

My major is biotechnology. This is a major which requires a very high level of English. Many papers in bioscience are using English as the publishing language. (Translation, Participant M from science program)

About $27 \%$ of the science major participants mentioned the importance of understanding academic vocabulary in English. Around 24\% of them needed to use English in academic communication such as making presentation and further study. Participant $\mathrm{N}$ had the following comment:

Many outstanding experts in our field are from abroad. Learning English well bridges the gap in knowledge. (Translation, Participant $\mathrm{N}$ from science program)

About $17 \%$ of the science majors needed to use English to write academic papers. Around 9\% hoped to follow the latest trend in the field. Participant $\mathrm{O}$ had the following view: 
Many new research results in the field are published first in English. Learning English can help to understand the latest knowledge and enhance academic communication. (Translation, Participant $\mathrm{O}$ from science program)

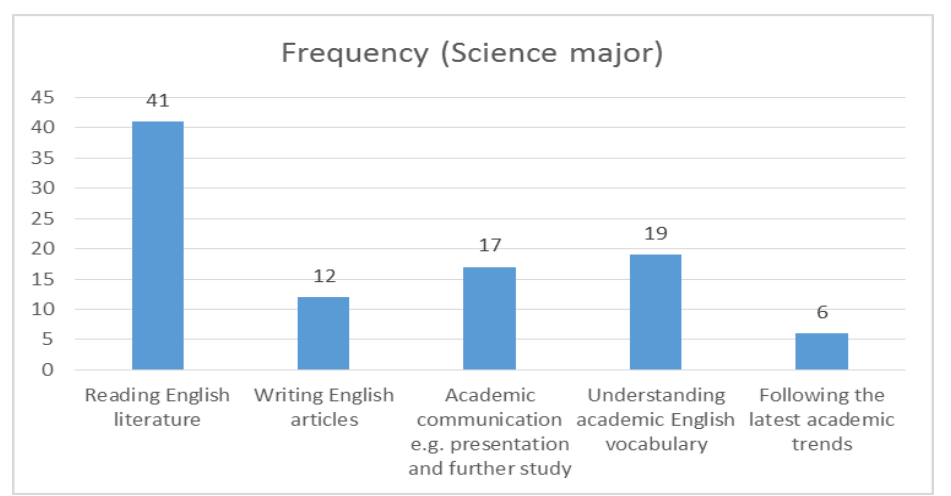

Figure 8. The Roles of English in Academic Study for Science Majors

Interestingly, English plays different roles in the academic study of language majors, which are described in Figure 9. About $47 \%$ of the language majors mentioned learning English helped to grasp the borrowing words in Japanese. Participant $\mathrm{P}$ had the following comment:

For a Japanese major student, learning English is important and necessary. In Japanese language, there are increasingly more borrowing words, mostly from English. Learning English to some extent facilitates Japanese learning. (Translation, Participant $P$ from language program)

Around 15\% of the language majors considered English as an important communication tool and $10 \%$ mentioned that English skill increased their competitiveness in the workplace or further study. About $7 \%$ of language majors mentioned the helpful roles of English when they were communicating with Japanese people. About $4 \%$ raised the roles of English which facilitated multiple language learning. Other roles mentioned by a small part of the participants included enhancing knowledge and horizon and literature reading.

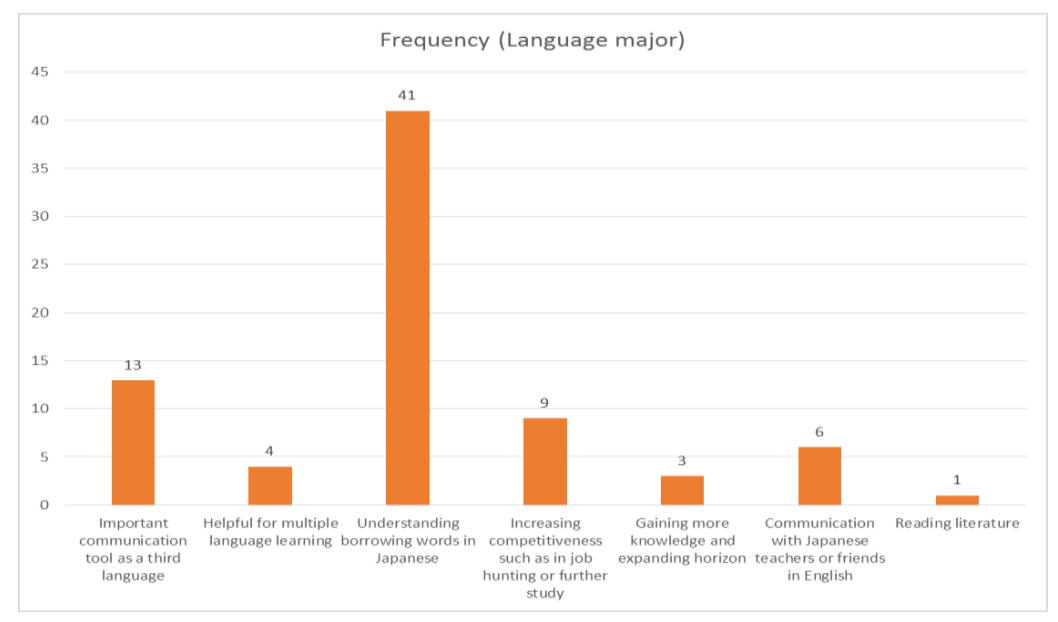

Figure 9. The roles of English in Academic Study for Language Majors

\subsubsection{The Situations and Contexts of English Use}

The situations of science and language major participants' communication with English speakers are described in Figure 10. For science majors, 23\% of the participants communicated in English with non-native English speakers, such as their English teachers and classmates. About 7\% of the participants communicated in English with both native and non-native English speakers. Only 4\% of the participants communicated in English with native speakers. The following two comments made by participant A and B described the real situations:

I communicated in English with mainly non-native speakers, because the university does not have many American people. There are not many chances. Mostly I communicate in English with non-native friends. (Translation, Participant A from science program) 
My supervisor is a Japanese. We communicated in English. My English course teachers are from Australia and China. (Translation, Participant B from science program)

For language majors, 25\% of the participants communicated in English with non-native speakers. About $10 \%$ communicated in English with both native and non-native speakers. About 8\% communicated in English with native speakers. Participant C, D, and E explained their experiences in English communication:

I mainly communicated with non-native speakers. My major is Japanese. My foreign teachers are non-native speakers. We occasionally use English to communicate. (Translation, Participant C from language program)

Native speakers: online friends from UK, US and Hong Kong, as well as friends I met in the volunteering activity in Kenya; non-native speakers: Japanese, Vietnamese. (Translation, Participant D from language program)

When I was studying in Japan, I met British and Japanese people. I communicated in English with them, but not very fluently. (Translation, Participant $\mathrm{E}$ from language program)

However, participants also indicated their problems in communication with native and non-native English speakers. Participant $\mathrm{F}$ and $\mathrm{G}$ had the following comments:

When I was communicating directly with native speakers, I cannot use the correct word. My mind got blank. (Translation, Participant $\mathrm{F}$ from language program)

When I communicate with non-native speakers, I mostly use "yes/no, hello, thank you, sorry". I communicated with native speakers twice, when I organized foreign friends to join in a tour and I was the guide. (Translation, Participant $\mathrm{G}$ from language program)

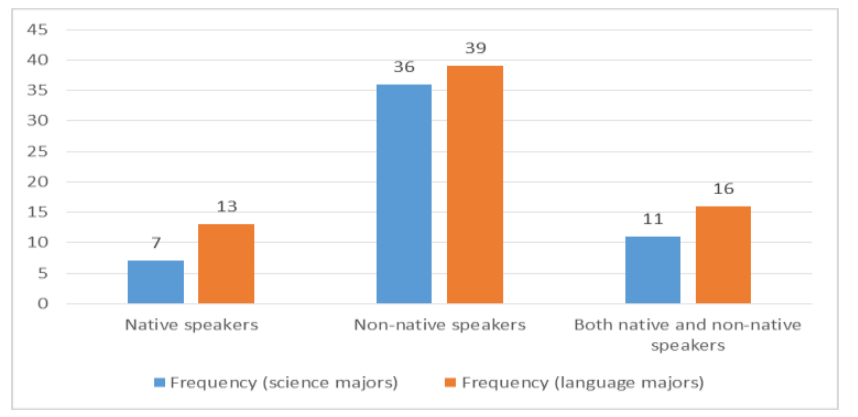

Figure 10. Communication with English Speakers for Science and Language Majors

Around $6 \%$ of the science major participants had short-term overseas travel or study experiences. Participant $\mathrm{H}$ had the following explanation:

I joined in US summer school and UK summer school. I also travelled to Australia with my parents. (Translation, Participant $\mathrm{H}$ from science program)

For language majors, $8 \%$ of them had study trip or travelling experiences in another country, such as Sri Lanka, Kenya, UK or US. Participant I described her three trips overseas:

I had 1-3 weeks study trips to US and UK in 2011 and 2015. I also had overseas study trip in 2012. (Translation, Participant I from language program)

The participants' contexts of English use during their academic study in the Chinese university are described in Figure 11. For science majors, $76 \%$ of them used English mostly on campus. This includes "English use in many places in the life, such as English videos, movies and games" according to participant J from science program. About $14 \%$ of the science majors used English both on campus and off campus. There was only one participant who mainly used English off campus.

For language majors, similarly, $67 \%$ of them confined the contexts of English use on campus, such as in the English classes. Participant $\mathrm{K}$ had the following comment:

Mainly on campus, such as in the English classroom. In the dormitory, we write English assignments and prepare for CET-4 and CET-6. We also watch American soap operas. (Translation, Participant K from language program)

Around $16 \%$ of language major participants used English both on campus and off campus. Participant L had the following experience: 
On campus, I mainly use English in class to answer teacher's questions. Off campus, I am having English tutor classes for a middle school student. There is too low frequency of English use. (Translation, Participant L from language program)

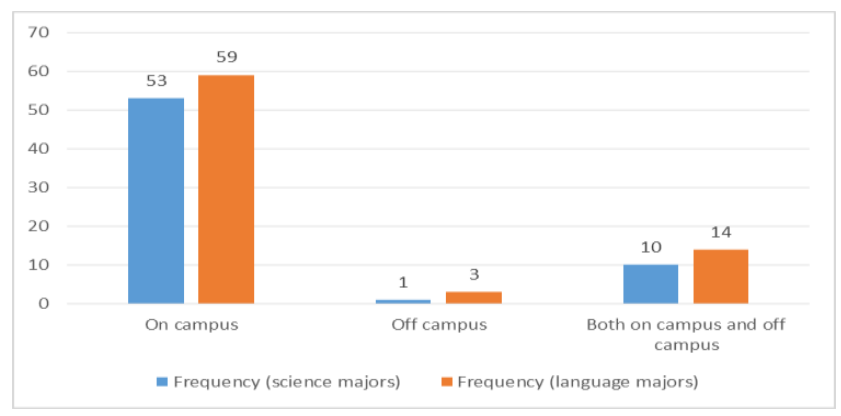

Figure 11. Contexts of English Use

\subsubsection{English Learning Situations}

For outside classroom English learning, the science major spent an average of 4.7 hours a week on English learning. There were individual differences, ranging from only 30 minutes to 10 hours per week. The self-directed out-of-class English learning for science majors included watching English videos, such as TED and memorizing vocabularies. However, a few participants from science programs claimed that they used English only in class.

For language majors, they spent an average of 5.7 hours a week on English learning out of class. This also ranges from 30 minutes to 36 hours a week. This included watching English movies and reading English books. A few participants from language program indicated that they would spend more hours in English learning if there were English classes. Participant J from language program had the following comment:

It depends on the situation during the week. I spent around 6 hours in English learning every week. The language I used most is Chinese, Japanese is the second, and the last one is English. (Translation, Participant $\mathbf{J}$ from language program)

While reporting on the previous English learning situations, $41 \%$ of science major participants reported various difficulties they experienced which lead to low level of English. The difficulties included a poor memory of English vocabulary, lack of interest in English learning and insufficient English speaking and listening skills. Participant Q had the following experience:

The main problem is lack of interest in English. But I know I must learn it well. I do not know how to study it well and from where to make a start. (Translation, Participant $\mathrm{Q}$ from science program)

About $27 \%$ of the language majors reported lack of adequate English skills due to low commitment to English learning and lack of motivation. They especially indicated inadequate English speaking and listening skills. Participant $\mathrm{R}$ had the following comment:

My English learning prior to university is exam oriented, which lead to my especially poor English speaking and listening. (Translation, Participant R from language program)

\subsubsection{The Importance of Business English for Career Development}

About 94\% of science major participants recognized the importance of business English for career development. Participants mentioned the needs for improving writing and reading skills and learning vocabularies. The needs for learning business English were job related, as shown in the comment by participant S:

I need to improve it. After I work, I may meet native English users. It would be more convenient for me to communicate with them. (Translation, Participant $\mathrm{S}$ from science program)

Similarly, $90 \%$ of the language major participants valued learning business English for their career development. There were the needs for improving reading and vocabulary in professional English. About $11 \%$ of them mentioned the direct link with future work. Participant $\mathrm{T}$ had the following vision:

As a Japanese major student, I hope to work for a Japanese company. English is also very important. I hope to learn real and practical business English, rather than only learning based on coursebook and preparing for exam. (Translation, Participant $\mathrm{T}$ from language program) 


\subsection{The Similarities and Differences in the Professional English Learning Needs and Situations of Science and Language Majors}

It can be seen that for class discussion participation, language major participants had higher frequency than science majors. More language major participants needed to do class discussion in every class. Similarly, in giving presentations, more language major participants had to do the task in every semester. According to the researcher's observation, this could be due to the differences in teaching methodology. The teaching of language such as Japanese requires more communicative teaching methodology while teaching of science relies more on demonstration and exposition.

As to the importance of professional English skills in academic study, science majors rated higher than language majors in professional reading and writing skills. Language majors rated higher in professional listening and speaking skills. This could be due to the fact that science major requires more literature reading and article writing in their study, rather than speaking and listening.

As to the roles of English in academic study, science major and language major participants had completely different needs. For science majors, the highest frequencies lie in English literature reading, including journal article and English websites, academic writing and communication. For language majors, it becomes learning borrowing words from English in Japanese.

For communication with English users, language majors communicated more with non-native speakers. Also more language majors communicated with both native and non-native English speakers. Language majors had more contacts with native speakers. Moreover, it seems that language majors had a bit more overseas travelling or study experiences, during which English use is needed.

For the contexts of language use, science majors had higher frequency of on-campus use, while more language majors used English in both on campus and off campus contexts. However, it is similar that the majority of science majors and language majors constrained the language use on campus, even only in English classrooms.

For outside class English learning, language majors spent more hours in English learning per week than science majors. The two groups had similar approach in outside class English learning, which includes watching English videos or movies. In particular, language majors are affected by the fact that they are learning a third language rather than English as a foreign language only.

There are more science major participants reporting difficulties or inadequacy in the English learning status, due to lack of motivations. Similarly, both groups had indicated the need for improving English listening and speaking skills.

It is also similar that both science and language majors had the majority of the two groups recognizing the value of business English learning for career development. More language major participants emphasized the connection with their future workplaces, such as working in a foreign company.

\section{Discussion}

Based on the comparison and contrast of professional English learning needs and situations of science and language major in the Chinese university context, suggestions for college English course development in the Chinese university can be given for improvement in teaching.

\subsection{Class Activities for College English Course}

As the majority of both science and language major participants had class discussion in their academic study, this approach is recommended to be adopted by also college English course. As more language major participants are ready for giving presentations for the academic study, it could become a usual approach for college English course for language majors. In contrast, giving presentations may not be a key component for the science group as there are lower expectations in doing the task. In the college English teaching in China, previous studies report difficulties in implementing student-centered method such as communicative language teaching due to class size incompatibility (Yang \& Yuen, 2014). Nevertheless, in this case, the adoption of communicative teaching methodology such as class discussion and presentation meet the learners' pedagogical needs.

\subsection{College English Course Tailored to Different Professional Learning Needs}

As science and language majors had different needs as English plays different roles in their academic study, the focus of college English courses should be different. According to the needs of science major participants, the college English course should offer more professional reading and writing training, especially in relation to English literature reading, article writing and academic communication. In contrast, for language majors, the focus should be more on communicative competence development, as it may facilitate multiple language 
learning and their own competitiveness for varied occasions. Previous research on ESP courses has also offered examples in which the college English course can be tailored to disciplinary needs such as teaching tertiary undergraduates writing for scholarly publication (Hyland, 2009).

\subsection{Promoting English Use for Different Contexts}

Moreover, the college English courses for both science and language groups should focus on solving their problems in the actual communication with both native and non-native English speakers. The course should enhance their communicative competence in the real world contexts. More overseas study trips could benefit them. The two groups should both be encouraged to use English more often in different contexts. In this case, the focus of English language teaching and learning should be shifted towards communicative competence development though previous studies in the similar context have found that the focus of English language teaching and learning in China is still examination oriented (Pan \& Block, 2011).

\subsection{Solving Learning Difficulties}

As to the English learning difficulties, the college English course should generate students' interest and motivate them to practice English communication skills both in classrooms and outside class. In this case, the focus should be geared towards developing English speaking and listening skills. Moreover, it is also suggested that college English teaching should ultimately develop students' communicative competence (Fang, 2010).

\subsection{Connection with real world workplaces}

In order to make business English for the two groups more effective, it is important to connect the classroom with the real world workplaces. It could enable the transfer of business English skills into practice. Previous ESP research also indicates the necessity of investigating workplace language use to inform business English classroom teaching (Evans, 2011).

\section{Conclusion}

This study investigates the professional learning needs and situations of science and language majors in a Chinese university context. There are both similarities and differences in science and language majors. Science and language majors in this Chinese university context have different purposes of learning professional English. The college English courses should tailor to the disciplinary specific learning needs. In addition, rather than focusing on examination, the college English courses in the Chinese university should promote English language use in the real world and enhance communicative competence development. The college English course should increase students' interests and motivation in learning. It should also enable the transfer of English language skills to the real workplaces.

This study serves as basis for further college English reform in China. It provides empirical evidence to support the transformation of college English course from English for general purposes only to more English for specific purposes orientation. The content of the college English course should be diverse to address the needs of disciplinary studies and communicative competence development for international workplaces. The study also has significant educational implications for English language teaching in the worldwide context and it recognizes that the course development process can be better enhanced through needs analysis research.

The limitations of the study lie in that it focuses only on one university context. Nevertheless the research process can be replicated in other educational or cultural contexts. Future research can address more widely other disciplinary sectors and conduct in-depth case studies to explore further opportunities of curriculum upgrading in English language teaching in the higher education context.

\section{Acknowledgements}

The author would like to express heartfelt thanks to the participants for their helpful contributions to the study. The author is also grateful for the expert comments from editors and reviewers for revising this article. This work was funded by 9th China Foreign Language Education Research Fund [ZGWYJYJJ2018B14].

\section{References}

Bacha, N. N., \& Bahous, R. (2008). Contrasting views of business students' writing needs in an EFL environment. English for Specific Purposes, 27, 74-93. http://doi.org/10.1016/j.esp.2007.05.001

Bao, X. M. (2016). An analysis of English majors' learning needs in the context of the reform of English education in China. Journal of Anshun university, 18(5), 66-68.

Basturkmen, H. (2010). Developing Courses in English for Specific Purposes. Basingstoke, New York: Palgrave Macmillan. https://doi.org/10.1057/9780230290518 
Brown, J. D. (2014). Mixed Methods Research for TESOL. Edinburgh: Edinburgh University Press.

Chen, Y. Y., Zhou, Y., Jiang, J. J., \& Wang, S. Q. (2012). Demand Analysis of Logistics English and its Implications. Academic Exploration, 4, 185-188.

Cheng, A. (2011). ESP Classroom Research: Basic Considerations and Future Research Questions. In D. Belcher, A. M. Johns and B. Paltridge (Eds.), New directions in English for specific purposes research (pp. 44-72). Ann Arbor, Mich.: University of Michigan Press,

Dörnyei, Z., \& Taguchi, T. (2011). Questionnaires in Second Language Research: Construction, Administration, and Processing (Second Edition). Beijing: Foreign Language Teaching and Research Press.

Dudley-Evans, T., \& St John, M. J. (1998). Developments in English for Specific Purposes. Cambridge: Cambridge University Press.

Evans, S. (2011). Hong Kong English and the professional world. World Englishes, 30(3), 293-316. http://doi.org/10.1111/j.1467-971x.2011.01655.x

Fang, F. (2010). A Discussion on Developing Students' Communicative Competence in College English Teaching in China. Journal of Language Teaching and Research, 1(2), 111-116. https://doi.org/10.4304/jltr.1.2.111-116

Guest, G., MacQueen, K. M., \& Namey, E. E. (2012). Applied Thematic Analysis. Thousand Oaks, Calif.: Sage Publications. https://doi.org/10.4135/9781483384436

Hyland, K. (2009). 4 English for professional academic purposes: Writing for scholarly publication. In D. Belcher (Eds.), English for Specific Purposes in Theory and Practice (pp. 84-103). Ann Arbor: University of Michigan Press.

Kaewpet, C. (2009). Communication needs of Thai civil engineering students. English for Specific Purposes, 28, 266-278. http://doi.org/10.1016/j.esp.2009.05.002

Leong, M. W. A., \& Li, X. J. (2012). A study on English teaching improvement based on stakeholders' needs and wants: The case of the Faculty of International Tourism of the Macau University of Science and Technology (MUST). Journal of Hospitality, Leisure, Sport \& Tourism Education, 11, 67-78. http://doi.org/10.1016/j.jhlste.2012.02.011

Li, R., \& Zhang, R. Q. (2010). Professional English learning needs of undergraduate nursing students. Chinese Nursing Management, 10(10).

Long, M. (2012). Second Language Needs Analysis. Beijing: Foreign Language Teaching and Research Press.

Mao, S. M. (2015). A chronological study of teacher-student cognition in EFL pedagogic innovations. Journal of Chongqing University: Social Science Edition, 2015(3), 196-201.

Ministry of Education, P. R. China (2004). Survey of the Educational Reform and Development in China. Retrieved from http://www.moe.edu.cn/publicfiles/business/htmlfiles/moe/moe_183/200401/2251.html

Pan, L., \& Block, D. (2011). English as a "global language" in China: An investigation into learners' and teachers' language beliefs. System, 39, 391-402. http://doi.org/10.1016/j.system.2011.07.011

Peters, P., \& Fernández, T. (2013). The lexical needs of ESP students in a professional field. English for Specific Purposes, 32, 236-247. http://doi.org/10.1016/j.esp.2013.05.002

Robinson, P. (1991). ESP Today: A Practitioner's Guide. London: Prentice Hall.

Serafini, E. J., Lake, J. B., \& Long, M. H. (2015). Needs analysis for specialized learner populations: Essential methodological improvements. English for Specific Purposes, 40, 11-26. http://doi.org/10.1016/j.esp.2015.05.002

Strevens, P. (1988). The learners and teachers of ESP. In D. Chamberlain and R. J. Baumgardner (Eds.), ESP in the Classroom: Practice and Evaluation (ELT Document 128) (pp.39-44). Hong Kong: Modern English Publications and the British Council.

Trinder, R. (2013). Business students' beliefs about language learning in a university context. English for Specific Purposes, 32, 1-11. http://doi.org/10.1016/j.esp.2012.06.003

Yang, J., \& Yuen, C. K. (2014). College English Teaching Methodology and Language Planning: A Pilot Study in Hefei, China. Procedia - Social and Behavioral Sciences, 118, 495-502.

http://doi.org/10.1016/j.sbspro.2014.02.068 
Zheng, P. (2015). Needs analysis of learners of English major in business English course. Journal of Qiqihar Junior Teachers' College, 2015-02, 147-149.

Zheng, Y. P. (2010). On Needs Analysis and College English Teaching in China. Journal of Language Teaching and Research, 1(4), 477-479. https://doi.org/10.4304/jltr.1.4.477-479

\section{Appendix}

Adapted from Basturkmen (2010, p.21), Dudley-Evans and St John (1998, p.140)

1. Name Gender Age

2. How would you describe your Business English level?

Beginner High Beginner Low Intermediate Intermediate High Intermediate Advanced Native Level

3. English Proficiency Test Score (e.g. CET-4, College Entry Test Score, IETLS, TOEFL etc.)

4. Please mark the best/primary reason for you to learn business English.

5. Please rate your level of overall motivation to learn English as _ (high/medium/low).

6. How important on a scale of $0 \sim 5$ are the following for success in your studies? 5 is very important and 0 is not important at all.

Professional writing

Professional speaking

Professional listening

Professional reading

7. Do you need to participate in class discussions as a part of your university studies?

Yes/No (please $\boldsymbol{V}$ )

If yes, how frequent are class discussions?

8. Are you required to give presentations?

Yes/No (please $\boldsymbol{V}$ )

If yes, how frequent are these presentations?

9. How many hours a week are you likely to use English?

10. Do you use English mainly on-campus or off-campus, or both? Please provide details.

11. Do you use English mainly with native speakers (for example Americans), non-native speakers, or both? Please provide details.

12. Please give details of previous English studies.

13. Please give details of extended visits/ stays in English-speaking countries.

14. Do you want to improve business English for your future career? How?

15. Please describe the roles of English in your academic study.

\section{Copyrights}

Copyright for this article is retained by the author(s), with first publication rights granted to the journal.

This is an open-access article distributed under the terms and conditions of the Creative Commons Attribution license (http://creativecommons.org/licenses/by/4.0/). 